\title{
State Constitutionalism and the Domain of Normative Theory
}

\author{
DANIEL B. RODRIGUEZ*
}

\section{TABLE OF CONTENTS}

I. INTRODUCTION .....................................................................................523

II. THE DISTINCT NATURE OF STATE CONSTITUTIONS...............................................526

III. FRAMING THE NORMATIVE QUESTIONS IN STATE

CONSTITUTIONALISM......................................................................................532

IV. THE DOMAIN OF NORMATIVE CONSTTTUTIONAL THEORY.....................................535

V. A FRAMEWORK EMPLOYING POSITIVE POLITICAL THEORY ..................................537

VI. CONCLUSION: THE INTEGRATION OF POSITTVE

CONSTTTUTIONAL THEORY AND NORMATIVE THEORY-

PERIS AND PAYOFF

\section{INTRODUCTION}

Political scientists and political economists who study processes of constitution making and systems of constitutional law are usually seen as doing something rather different than the work of those of us who ponder prescriptive constitutional theory. We share, of course, an interest in constitutionalism, politics, and law. Moreover, we have come to think in modern academic discourse that social science conceptions of

* Dean and Professor of Law, University of San Diego School of Law. J.D. 1987, Harvard Law School; B.A. 1984, California State University. This Essay was originally prepared for a conference on state constitutional law at the University of New Mexico School of Law. The ideas contained herein benefited from the participants at that conference and also from my colleagues at both Boalt Hall School of Law and the University of San Diego School of Law. 
constitutionalism are incomplete without a substantial understanding of the role of law and, more particularly, without an appreciation for the fact that much of American constitutionalism is infused with normative theory. We believe as constitutional lawyers that our legal scholarship is impoverished without a rich understanding of the political and economic foundations of constitutions and the processes of constitution making. Nevertheless, as legal scholars interested in constitutional questions, we think we are doing something different than the work of political scientists and political economists.

This disjunction is especially troubling for those of us who are simultaneously interested in issues of positive constitutionalism and normative constitutional theory. Positive constitutionalism means not only describing but also theorizing about elemental questions of constitutional structure and theory. Key positive questions include: Why do certain constitutional forms emerge and survive? What is the role of political choice, by legislators and by citizen voters, in constructing constitutions and constitutional discourse? What is the relationship between constitutionalism and constitutional law? By normative constitutional theory, I mean the critical evaluation of constitutions. The key normative question is: What ought a particular constitution say? Those of us interested in both positive constitutionalism and normative constitutional theory would like to think that we are bringing together the inquiries of both of these areas-not only to reiterate the trivially true point that there are inevitably normative elements in positive constitutionalism and vice versa, but also to further the agenda of improving constitutions and constitutional law. Therefore, we resist the traditional division of functions between those who are preoccupied with positive constitutionalism and those who toil primarily on normative questions.

To the ear of someone whose enterprise is principally understanding and interpreting the United States Constitution, this endeavor to draw together positive constitutionalism and normative theory sounds perhaps abstract at best, and anachronistic at worst. After all, what utility is there in obsessing over the role of political choice by legislators and citizen voters in constructing constitutional discourse, except as part of the

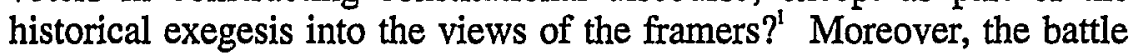

1. Such exegesis forms an important part of recent scholarly discourse on constitutional theory pertaining to the Federal Constitution. Indeed, the $1990 \mathrm{~s}$ are proving an especially fertile time for neo-historical examinations of positive constitutionalism. See generally LaURA KaLMAN, THE STRANGe CAREER OF LEGAL LIBERALISM (1996) (describing neo-originalist writings); JACK N. RAKOVE, ORIGINAL MEANINGS: POLITICS AND IDEAS IN THE MAKING OF THE CONSTITUTION (1996). At the same time, mainstream constitutional theory continues to march ahead as principally a 
for interpretive supremacy has been long waged and decisively won by the courts. Judges, especially the Supreme Court, are the principal audience for prescriptive analysis; structural questions concerning constitutional architecture and the resilience of constitutional strategies and the like are pertinent only insofar as they shed light on the sorts of normative arguments which "count" with judges. This does not mean that, from the perspective of constitutional scholars of the U.S. Constitution, there is nothing to the careful study of positive constitutionalism, but it does tend to diminish the imperative of drawing together positive constitutionalism and normative theory.

A different challenge faces those of us preoccupied with state constitutional law and the relationship among levels and layers of government within a state constitutional system. We are interested in how our states confront challenges concerning regulation, politics, institutional design, and social and economic goods and services. Moreover, we are interested in how state constitutionalism as a more or less coherent theoretical apparatus addresses ubiquitous questions of institutional design and competence. The descriptive questions concern what we see, and what we think about what we see, when we look into state constitutional forms; the normative question concerns how to make the system work better. However quaint these questions sound to folks steeped in federal constitutional discourse, they are real and enduring when examined through the lens of state constitutionalism. ${ }^{3}$

The questions are real and enduring because of qualities characteristic of state constitutions and their particular and general histories. These qualities are distinct from our federal Constitution in ways that make pertinent our attention to the intersections of positive constitutionalism and prescriptive theory. Further, these distinctions help shape the domain of normative theory within which our efforts are carried out.

normative enterprise. See, e.g., Symposium, Fidelity in Constitutional Theory, 65 FORDHAM L. REV. 1247, 1247-1818 (1997).

2. We may be interested in this from the perspective of one particular state or from a comparative perspective, with the 50 states as our laboratories. See, e.g., G. ALAN TARR, UNDERSTANDING STATE CONSTTTUTIONS 6-28 (1998).

3. See generally Daniel B. Rodriguez, State Constitutional Theory and Its Prospects, 28 N.M. L. REV. 271 (1998) (tracing the framework within which one creatively thinks about state constitutional theory). 


\section{The Distinct Nature of State Constitutions}

American state constitutions are documents shaped over the course of two centuries. All but the original thirteen states came into the union with their constitutions, after the establishment of the national constitution. Many of these post-1787 state constitutions track in important respects national constitutional discourse-including the establishment in each document of a separation of powers and, in all but one, a bicameral state legislature. They also each contain a bill of rights, containing collections of rights that are, for the most part, at least as protective of individual liberty as those embodied in the national constitution. ${ }^{4}$ But it is here that the similarities end.

The first of four critical distinctions between federal and state constitutions is that state constitutions are documents of limit rather than grant. ${ }^{5}$ The essential notion of the state police power expresses the core idea of the state legislative and executive power under principles of state constitutionalism, which is that state political entities may exercise all powers necessary to carry out state goals, except as limited by the national constitution. These goals are, of course, to be defined by state political institutions. From the perspective of constitutional theory more generally, this principle is both peculiar and fundamental. It is peculiar to lawyers steeped in the American national constitutional tradition, wherein the basic idea that the federal government has limited powers is primary. ${ }^{6}$ The states' police power and the corollary that state constitutions are documents of limit, not grant, are the direct inverse of this. It is fundamental, for it tends to construct the system of state decision-making around the ideology of political discretion and choice, rather than around an ideology of the rule of law. This is especially important with respect to the relationship between state political institutions and local governments. Whereas states occupy an essential role in the American constitutional system, the notion that there is an equivalent principle of federalism-or "Iocalism"-in state constitutionalism is highly contested. ${ }^{7}$ It is commonplace to observe that

4. See Robert F. WILliams, State Constitutional LaW: Cases and MATERIALS 171-87 (3d ed. 1999); William J. Brennan, Jr., State Constitutions and the Protection of Individual Rights, 90 HARV. L. REV. 489, 491 (1977).

5. See Eugene McQuillin, Constitutional Right of Local Self-Government of Municipalities, and Principles Applicable to Central Control, 35 AM. L. REv. 510, 522 (1901). A document of limit imposes constraints upon a presumption of unlimited power. By contrast, a document of grant creates certain enumerated powers for an otherwise powerless entity.

6. See, e.g., M'Culloch v. Maryland, 17 U.S. (4 Wheat) 316, 405 (1819) ("This [federal] government is acknowledged by all, to be one of enumerated powers.").

7. The term "Iocalism" has confused things somewhat by borrowing an analogy from discourse about federalism. See generally Richard Briffault, Our Localism: Part 
local governments are creatures of the state. ${ }^{8}$ Therefore, the plethora of legal questions raised by state and local conflicts in the fifty states occupies a fundamentally different conceptual ground than the enduring questions of federalism that are part of the structure of constitutionalism at the national level.

The second key distinction between the federal and state constitutions concerns the frequency of amendments over time. Although more practical than theoretical, the observation of such a difference has a considerable impact on the nature of the positive enterprise, whether considered by social scientists or by legal scholars. The national constitution, as is well known, is remarkably impervious to change, especially when measured against the constitutions of other nations and those of the fifty American states. A mere sixteen amendments separate us now, in the year 2000, from our predecessors in 1789 when the constitution, with the first ten amendments, was adopted as fundamental law.' Calls for a national constitutional convention have gone unheeded; attempts to amend the Constitution have mostly been defeated. ${ }^{10}$ Interestingly, the efforts to defeat various amendment initiatives have employed a rhetoric that stresses not only the undesirability of particular proposals, but also the caution we should exercise prior to marring this enduring document. ${ }^{11}$

I-The Structure of Local Government Law, 90 COLUM. L. REV. 1 (1990). Federalism expresses not merely, or especially, a principle about national-state relations, but rather a core constitutional principle of power allocation. See DAVID L. SHAPIRO, FEDERALISM: A Dialogue 58-75 (1995). Perhaps critics of federalism are correct in regarding the concept of federalism as anachronistic in the modern administrative state. See, e.g., Edward L. Rubin \& Malcolm Feeley, Federalism: Some Notes on a National Neurosis, 41 UCLA L. REv. 903, 903-09 (1994). Or perhaps they are wrong. See, e.g., SHAPIRO, supra, at 58-106; Larry Kramer, Understanding Federalism, 47 VAND. L. REV. 1485, 1560-61 (1994). But tying federalism as a constitutional principle to questions of national/state economic, political, and social relations requires a substantive argument. Likewise, insisting that there is something called our "localism" that describes the relationship between local governments and the states requires not only a political and economic argument for local prerogatives and power, but also a coherent political theory that explains why localism is properly a part of state constitutionalism.

8. See Hunter v. City of Pittsburgh, 207 U.S. 161, 178 (1907).

9. The first ten Amendments, commonly called the Bill of Rights, were ratified in 1791. Although technically there have been 27 Amendments, the Eighteenth Amendment was later repealed. See U.S. CONST. amend. XVIII, repealed by U.S. CONST. amend. XXI.

10. See Alexander Hanebeck, Democracy Within Federalism: An Attempt to Reestablish Middle Ground, 37 SAN DIEGO L. REV. 347, 395-98 (2000) (examining failed proposed amendments).

11. See id. 
This rhetoric would seem rather strange in the context of state constitutional discourse. State constitutions are, on average, much longer then the U.S. Constitution. Moreover, state constitutional amendments are frequent, if not routine. This Essay does not propound a theory of why we amend state constitutions so readily when we cannot bring ourselves to do likewise in the federal area; the national constitution is impervious to change mostly because it is slightly more difficult to amend than are state constitutions. The basic point is the descriptive one: state constitutional forms are considerably more contingent and transient than national constitutional forms. State constitutions, while not up for grabs, permit and promote fluid, politically salient, and reformist impulses.

There are a number of ways in which this fluidity shapes intellectual discourse. To begin with, the amenability to change means that, so far as the state constitution is concerned, there is more that is fundamental to fight about. In one of California's most recent passes at reform, there were proposals calling for a unicameral legislature, for radical surgery on the executive branch, and for altering the balance of power between state and local governments. ${ }^{12}$ There are a myriad of less far-reaching reforms as well. Much of the debate involves contests over the basic terms of state constitutional discourse and constitutional structure. It is impossible to have such conversation without articulating the competing visions of constitutionalism. To have effective reform discussions, then, we must tie together positive constitutionalism and normative theory. We are, after all, haggling over the fundamentals of state constitutional architecture. Rarely have we seen such fundamental contests waged at the national level. Perhaps the New Deal was the last time, as Bruce Ackerman argues; ${ }^{13}$ however, even then most of the structural terms of the debate-for example, whether we would preserve a unitary presidency, a bicameral legislature, some separation of powers, and federalism-were essentially off the table.

Many of these fundamental debates being waged at the state constitutional level-now, and frequently in the past-concern issues of constitutional structure. This is highly unusual when compared with traditional federal constitutional discourse. No one believes that the presence and prevalence of rights in state constitutions is unimportant; on the contrary, what we often describe as the revival of state constitutional law and theory in recent years owes a great debt to the efforts of the late Justice William Brennan and others who insisted that

12. See Constitutional Reform in California: Making State Government MORE EFFECTIVE AND RESPONSIVE (Bruce E. Cain \& Roger G. Noll eds., 1995).

13. See BRUCe ACKERMAN, We the PEOPLE: Foundations 99-104 (1991). 
the key to augmenting individual liberty in an era of judicial conservativism was through vigorous articulation and enforcement of state constitutional rights. ${ }^{14}$ However, most current political debates over state constitutional reform involve not issues of individual rights, but governmental structure and the balance of powers.

If we pause to think about the range of contemporary policy issues that constantly come under scrutiny in the popular press and in academic commentary-criminal justice, welfare reform, the state of our cities, racial justice, and economic opportunity-we see that these issues frequently are framed around calls for reforming state political, legal, and economic institutions. It is not that federal intervention is being ignored; it is rather that the reality of our current political situation is that widespread federal intervention along the model of the War on Poverty, and even more modest initiatives such as general revenue sharing, is unfashionable. "Devolution" is the theme of the day; what this devolution means in practice, rather than as a slogan, is the reformulation of state and local strategies for policy change. ${ }^{15}$ For constitutional lawyers, the challenge is to think creatively about how state constitutionalism can confront this challenge. What are the obstacles? What are the opportunities? Given the nature of these modern challenges, it ought not to surprise us that the key contests are over structural constitutional issues. When discussions roam over the range of contemporary constitutional forms, such as the bicameral state legislature and the modern system of municipal management, sophisticated analysts are likely to tie the discussion of the costs and benefits of these forms to substantive policy debates. ${ }^{16}$

An aspect of constitutional discourse that reveals the third difference between federal and state constitutionalism is a shift in focus from courts as the ultimate audience for normative constitutional theory to the legislature and administrative agencies. When constitutional law is

14. See Brennan, supra note 4, at 491 ("State constitutions... are a font of individual liberties, their protections often extending beyond those required by the Supreme Court's interpretation of federal law.").

15. See Paul E. Peterson, The Price of Federalism 69-75 (1995).

16. While the contrast between the policy-laden debates in state constitutional discourse and the more rarified debate in federal constitutional discourse is striking, there are conspicuous counterexamples that illustrate the potential of policy-sensitive constitutional argument at the national level. See, e.g, ALAN BRINKLEY ET AL., NEw FEDERALIST PAPERS: ESSAYS IN DEFENSE OF THE CONSTITUTION (1997) (offering creative ideas about how the Federal Constitution can, and ought to, respond to modern challenges). 
regarded as the business of the courts, normative debate is shaped around the distinct enterprise of adjudication. The most conspicuous efforts at deep constitutional theory from both the right and the left have, naturally, concentrated on judicial decision-makers. State constitutional decision-making is, as previously discussed, the product of political choice by legislators and agencies, as well as by judicial decree. While federal constitutional decision-making entails inter-institutional action in theory, processes of state constitutional decision-making ought to reflect such institutional eclecticism as a matter of common practice.

This shift from courts to legislatures affects the dynamics of normative constitutional theory in interesting ways. The constitutional rhetoric available to individuals and interest groups looking to influence public policy in legislatures and agencies is different from the typical rhetoric of legal argument in courts. Adjudication, as Lon Fuller reminded us over a quarter century ago, has a distinct logic and a particular series of intellectual moves and agendas. ${ }^{17}$ We may make legal arguments to legislatures, and we certainly develop law through administrative decision-making. Yet different expectations, roles, and practical judgments shape this process. Not only are the fundamentals of the legislative and administrative agenda different than the more narrow agenda of constitutional adjudication in courts, but the institutional matrices within which legal and political judgments are made are importantly distinct. ${ }^{18}$ Moreover, these differences can be expected to shape reformists' expectations and hence their reform strategies. Where constitutional politics become, to borrow from Professor Ackerman's framework, part of the processes of "normal" politics, ${ }^{19}$ and where, therefore, legislatures and agencies become among the prime state constitutional architects, the mechanisms that are created in order to influence these political processes take a certain form. For example, if the centrality-or, at least, the exclusivity-of constitutional adjudication as a method for framing constitutional discourse is replaced by legislative, administrative, and citizen/grass-roots action, then the pressure groups who regularly participate in state constitutional politics will organize their strategies accordingly. This deliberate organization, in turn, reinforces the system of constitutionalism. This "strategic" explanation may help us understand why state constitutional decisionmaking continues to proceed on a very different track than federal constitutional decision-making and, as will be argued in Part III, why it

17. See generally Lon L. Fuller, The Forms and Limits of Adjudication, 92 HARV.

L. REv. 353 (1978) (providing a detailed analysis and definition of adjudication).

18. See ROBERT M. COVER ET AL., PROCEDURE 1-37 (1988).

19. ACKERMAN, supra note 13 , at 230. 
is necessary to understand better the domain of normative theory in state constitutional law.

The fourth and final elemental difference relates directly to the shift in focus from courts to legislatures and agencies as the key arenas in which constitutional discourse is shaped. Constitutional adjudication is attached firmly in our minds to a conception of the constitution as grand law; constitutional theory is grand theory. The rewards and incentives in a variety of institutional contexts, from the organized bar to the legal academy, reinforce the idea that shaping constitutional law through theories of constitutional adjudication is the high calling of prescriptive theory. This theory building has, perhaps paradoxically, proceeded with little interpenetration by insights into the structure and practice of the judiciary as a legal institution. Political scientists who do "public law" are in a rather marginal position vis-à-vis the main exponents of normative constitutional theory in the legal academy; the reverse is true as well. Constitutional theory as developed in traditional legal discourse is sharply criticized by political scientists as a naive and unrealistic depiction of modern judicial practice. Constitutional theorists resist this critique pretty well, however, by guarding the temple of normative constitutional theory from inroads by positive constitutionalism and institutional exegesis. What is at stake is not merely the disjunction between the "is" and the "ought," but, more pertinently, whether we ought to continue to instantiate constitutional adjudication as the highest, purest form of legal craftsmanship.

This account of constitutional theorists is intended neither as a caricature nor as part of an argument for or against their view. This Essay only suggests that the ascription of "high lawcraft" to constitutional adjudication that characterizes most of mainstream constitutional theory today should be tied tightly to the agenda of constitutional theorists who study the federal Constitution. Whether it is or ought to be tied quite as tightly to state constitutional theorists remains an open question. Perhaps constitutional adjudication is pedigreed because this is where most theorists believe that constitutional decision-making takes place. This is, as it were, much like the story of the man who looks for his keys where the light is best. Or perhaps the pedigree is attached to adjudication because of a substantive theory that explains why constitutional adjudication ought to be distinct from, say, the political judgment that infuses decision-making in nonjudicial institutions. Ronald Dworkin, for example, surely has an embedded 
theory of judicial decision-making through adjudication within his general theory of legal interpretation; ${ }^{20}$ one could hardly substitute Congressman $X$ or Administrator $Y$ for Hercules in Dworkin's account. ${ }^{21}$ Nor could legislators and administrators fit the bill as judicial decisionmakers under most modern theories of constitutional interpretation, which rest on assumptions about the comparative institutional competencies of different legal institutions.

However, when we turn the light toward state constitutional decisionmaking, we ought to clearly specify our assumptions and theories about adjudication versus legislation versus administration in a state constitutional system. Our expectations of state judges may come to be altogether different from our expectations of federal judges. Many state judges are chosen by a process that significantly differs from the federal system. Given this fact, it would be surprising if the structure of incentives were identical between these two levels of government. Moreover, state legislatures and agencies, as political units and sources of legal power, vary significantly among the fifty states, and these differ collectively from their federal counterparts. In light of these differences, we are entitled to ask: (1) Is the state constitution grand law, necessarily to be developed through the discourse of constitutional adjudication, in the same way the federal Constitution is developed? (2) Is state constitutional adjudication a distinctly normative process for the articulation and interpretation of public values and the deployment of special legal judgment and wisdom, or is the legislature equally well suited to receive normative constitutional argument?

\section{Framing the Normative Questions In State CONSTITUTIONALISM}

Positive constitutionalism and normative constitutional theory ought to be tied more closely together as a research enterprise with regard to issues arising under state constitutions. The reasons, as spelled out in the previous section, concern characteristics particular to state constitutionalism as a subject of inquiry. Moreover, there should be a more careful consideration of how to frame the normative questions we are asking. We need to have a sense of the domain of normative theory in light of our positive theories of constitutionalism and of constitutional law.

Consider this example: States regulate the contours of local

20. See RONALD DWORKIN, LAW'S EMPIRE 45-86 (1986). (1999).

21. See the discussion in JEREMY WALDRON, THE DiGNITY OF LEgISLATION 7-35 
government fiscal policy in a myriad of ways. In California, for example, there are severe restrictions on the power of local governments to raise revenues through the property tax.22 There are limits on the amount of municipal debt that a locality may incur to finance local services, ${ }^{23}$ there are constitutional "public purpose" requirements designed to cabin private interest group influence, and there are, because of an omnibus constitutional initiative recently enacted, a series of limitations on the scope of municipal authority to raise revenues through special assessments, user fees, and other local taxes. ${ }^{24}$ The global normative question raised by this constitutional structure is whether and to what extent these constitutional rules serve aims we regard as attached to our theory of state and local finance and also to our theory of state/local relations under the state constitution. Yet, the only way that this normative discussion can make sense is with a richer, more textured sense of what our constitutionally created policy aims to accomplish with this set of constitutional rules of fiscal policy.

There are competing and very different perspectives, regarding such policy aims. Suppose, for example, we think that the state has a stake in setting up a fiscal framework within which local decisions are made because there is a comprehensive fiscal philosophy that undergirds the state constitution. We could suppose that the state is concerned with assuring a fiscal environment in which businesses are attracted to the state, poorer residents are disinclined to stay, and, overall, the state is enabled to compete successfully with other states for goods and services. Since, after all, the state constructs its own public economy and since local governments are regarded as creatures of the state, we could imagine that the state manages its fiscal affairs by treating localities as administrative units created and regulated in order to carry out the state's comprehensive economic agenda.

This is a plausible depiction of the state's constitutional philosophy with respect to fiscal affairs, but this is not the only possible depiction. We might have a very different perspective on the positive theory underlying state fiscal choices. Suppose that we think the state's only commitment is to construct rules of the sort that structure local decisionmaking, but without an eye toward accomplishing any particular approach to governance or ultimate policy end. Here, we might imagine

22. See CAL. ConsT. art. XIIIA, \& 1 .

23. See CAL. Const. art. XVI, \&1.

24. See CAL. CONST. art. XIIID, $\S 1$. 
that the state treats local governments as substate units of government, as part of the state polity. These units of government are entitled, in the view of the state, to create their own policy agendas and to pursue these agendas through creative use of available fiscal instruments. This view bears a relationship, after all, to how cooperative theories of federalism treat the relationship between the national and state governments under the Constitution. In this light, states have a two-fold agenda. They are interested in creating rules that enable localities to pursue agendas, but not where these agendas come into conflict with other local intereststhis is the problem of externalities-and not where these agendas come into conflict with the state's interest in managing its own fiscal affairsthis is the problem of conflict.

It is not this Essay's aim to unpack in any more detail these two competing models of state constitutional philosophy in the fiscal realm. Rather, it aims only to indicate that these two models rest on very different positive theories of constitutionalism and constitutional ideology; they also point to very different prescriptions. If, for example, we think that the state constructs state/local fiscal relationships in order to further a statewide aim, then we can evaluate constitutional strategies in light of this aim. Part of our prescriptive analysis, in such case, will entail a study of whether and to what extent certain fiscal strategies enable or retard the state's ability to carry out its discernible policy agenda. This structure of normative analysis will look different if we begin with a positive theory of the fiscal constitution that stresses the state's basic agnosticism with respect to local fiscal choices. At bottom, these two competing perspectives point to two very different models of state/local decision-making; they build, as well, upon very different positive theories of state political decision-making and constitutional philosophy.

To be sure, we also face questions of constitutional principle when we scrutinize carefully the national Constitution. Yet, our approach to discerning the positive theory of state constitutionalism is necessarily more eclectic. After all, there is hardly a discernible philosophical vision located in the choices of "framers" at a particular moment in time. There is, for the most part, no defining moment in which the state constructs its constitutional ideology. Or, if there are some moments, they are confounded by the postframing changes in constitutional structure-the frequent amendments, the subconstitutional choices made by state political actors under the norm of the police power, and the constitutional initiatives that represent the interventions of citizen voters in shaping constitutional change. It is, in the end, tremendously difficult to tackle normative questions of constitutional decision-making with references to a discernible constitutional ideology manifest in the state 
constitution's text, its history, or its philosophy.

This does not mean that we ought to abandon normative theories of state constitutionalism and constitutional law. On the contrary, the normative questions are, if anything, more eclectic and fruitful. They are eclectic to the extent that we are addressing not only narrow questions of judicial rules and doctrines, but also questions of structural design and institutional performance. They are fruitful to the extent that many more issues of constitutional law and public policy are up for grabs in the states. The fluidity of state constitutional discourse connotes not only instability, but also opportunity for change. If "government by reflection and choice" is the normative label attached to our constitutional traditions, then perhaps reflection is the term especially well suited to federal constitutional debate, and choice is more properly attached to state constitutions.

\section{The Domain OF Normative Constitutional THeORY}

This characterization of state constitutionalism has implications for constitutional discourse and normative constitutional argument. If normative constitutional theory in connection with state constitutionalism is seen as largely a product of political choice and nonjudicial institutional decision-making, then we ought to think more creatively about how to make arguments tailored to particular institutions. Part of the agenda of the Legal Process movement was to describe more systematically the comparative institutional competencies of legislatures, courts, and agencies, and the different sorts of decisionmaking mechanisms available to these diffuse institutions. ${ }^{25}$ This Essay is in harmony with these Legal Process efforts.

How would the constitutional discourse look different? Let us return to the example of constitutional construction of local fiscal policy. In contemporary California, many of the fundamental fiscal choices otherwise available to local governments have been constricted by operation of constitutional amendments. Proposition 13 and its progeny substantially limited the availability of the property tax; they also imposed supermajority requirements on local efforts to raise money through other taxes. ${ }^{26}$ Additionally, the recently enacted Proposition 218

25. See NEIL DUXBuRY, PATTERNS OF AMERICAN JURISPRUDENCE 205-99 (1995).

26. See CAL. CONST. art. XIIIA, § 1 . 
imposes a wide range of legal limits on localities' taxing authority. ${ }^{27}$ From the perspective of constitutional adjudication, there is little left to decide in terms of the operation of these initiatives; both, after all, amend the constitution. Moreover, they were drafted carefully in order to avoid the need for constant interpretation.

Yet, from a presumptive standpoint, we could concentrate our constitutional discourse on efforts to refashion the structure of fiscal policy. The point is not merely to convince voters or the legislature to repeal the initiative; rather, the enterprise is to think creatively and systematically about how to integrate certain constitutional principles and structures into a framework of state/local relations of state fiscal policy. One perspective on California's twenty-five-year experiment with fiscal reconstruction-the "taxpayers' revolt"-is to view California as gradually shrinking the public sector. The interests at stake in these efforts are the private sector and individual property owners who have, so the argument goes, seen their financial hegemony shrink in the face of expanding local regulatory and taxing power. There are, however, other perspectives on what is transpiring. One perspective is to see the state as reigning in local governments in order to preserve a more rational, scientific system of state/local finance. The principal "evil," in this view, to which efforts such as Propositions 13 and 218 are directed, is local fiscal mismanagement and irresponsibility. The agenda is not to shrink the public sector; the state does not intend for the local fiscal systems to wither away. Instead, California is grasping toward a system of comprehensive fiscal rationality in which both the basic and the specific elements of fiscal policy, especially through the operation of the tax system, will be delineated through state constitutional commands.

The structure of normative constitutional theory as it pertains to these sets of issues will look quite different depending upon which of the aforementioned perspectives we adopt. Further, this way of framing the issue demands close attention to positive constitutionalism insofar as we attempt to understand why the state is doing what it is doing. We are concerned not only with the policy agendas underlying these fiscal initiatives, but also, as constitutional theorists, with why the voters press ahead with constitutional approaches. The domain of normative theory is marked ultimately by the shape of constitutional decision-making in a particular state or in state constitutional systems generally. At the same time, the shape of constitutional decision-making-for example, whether $X$ or $Y$ policy ought to be embedded in the state constitution, rather than in "mere" legislation or administrative decree-is constructed in part by

27. See CAL. Const. art. XIIID, $\S 3$. 
normative constitutional argument.

One might want to highlight that this reveals nothing more or less than the rather abstract observation that law is deeply influenced by politics and vice versa. This dose of legal realism, while appropriate, is not particularly tied to debates about state constitutional theory. However, it is necessary to return to the earlier discussion of the nature of state constitutions. As discussed, the fluidity of state constitutional decisionmaking affords contention on many issues which, when viewed through the lens of federal constitutional theory, would be largely beyond controversy. There is, simply put, much more at stake in constitutional discourse directed to legislatures, to governors, to administrative agencies, and to local officials. It is not enough to stress the point that the contours of constitutional law in the state constitutional area are formed by political actions in a distinct way; we need to continue toward the heart of the matter by considering how the politics of state constitutional decision-making and constitutional change ought to be understood. What is required is a theoretical framework for understanding state politics and state institutions. This is necessary not only to provide ground for our theories of positive constitutionalism, but also to mark the domain of normative constitutional theory.

\section{A FRAMEWORK EMPLOYING POSITTVE POLITICAL THEORY}

What would such a framework look like? One emerging body of theory that is especially fruitful, if still somewhat underdeveloped and untested, is called positive political theory. ${ }^{28}$ Daniel Farber and Philip Frickey, in an introduction to a symposium of the same name, define the phrase as the "non-normative, rational-choice theories of political institutions." ${ }^{29}$ The basic idea is this: Decision-makers act within political institutions to accomplish a complex series of aims; reelection is certainly one incentive, but so too is the agenda of pursuing the public good. Motivations of political decision-makers, like the motivations of all humans, are complex and evolving. Yet these decision-makers must, after all, make decisions. They do so within a matrix of institutions that are not inherited and fixed, but rather fluid and constructed. Many of the

28. See generally Daniel B. Rodriguez, The Positive Political Dimensions of Regulatory Reform, 72 WASH. U. L.Q. 1 (1994).

29. Daniel A. Farber \& Philip P. Frickey, Foreword: Positive Political Theory in the Nineties, 80 GEO. L.J. 457, 462 (1992) (emphasis omitted). 
institutional choices we often take for granted-such as the existence and persistence of the bicameral legislature, the delegation of broad regulatory power to agencies, the system of consideration for proposed legislation, and decision rules in courts-are the product of rational action by decision-makers. Sometimes these decisions are made in concert, with a suitable majority of legislators signing on to particular institutional forms on the theory that these institutions will, on the whole, contribute to the purposive agendas of all legislators in the aggregate and over time. Other times these decisions represent the strategic, calculating moves by legislators acting in an environment that rewards, through incentives and resources, such strategic behavior. Positive political theory steers our attention to the ways in which decision-makers in public institutions make strategic choices. More precisely, this body of theory builds upon the contributions of rational choice theorists in political economics, philosophy, game theory, and other fields in order to form testable hypotheses concerning political action.

Positive political theory does not, by its own terms, tell us anything about what to do with these positive frameworks. However, the domain of normative constitutional theory is shaped powerfully, and for reasons described throughout this Essay, by theories of positive constitutionalism. For example, positive political theory suggests to us that one of the factors that goes into legislative decisions to remove certain policy issues from the political table and embed them in constitutional forms is to decrease the opportunities for rent-seeking behavior by politicians acting through normal political devices. So, one plausible explanation for the constitutionalization of local fiscal policy along the lines suggested by California's recent efforts is that state decision-makers fear the competition for economic rents by localities and hence will act to limit the domain of local political choice. If we think that it is prudent for local decision-makers to compete with the state, perhaps because such regulatory competition represents a beneficial check on aggrandizing behavior by the central state, then we might resist this process of constitutionalization of fiscal policy. Moreover, we might direct our normative constitutional argument toward decision-makers that we trust as being removed somewhat from these political incentives. Or we might see the normative agenda as being about imposing more substantial costs on the legislature to move in these limiting directions. Efforts to limit statewide initiatives to a single subject, for example, have this normative quality. 


\section{CONCLUSION: THE INTEGRATION OF POSITIVE CONSTITUTIONAL THEORY AND NORMATIVE THEORY-PERISS AND PAYOFF}

In the end, we need positive frameworks of state constitutional decision-making in order to understand the uses to which we can put our normative arguments. The alternative is to detach normative debate from positive constitutionalism altogether. This Essay suggests that this detachment is characteristic of much of current constitutional theory with regard to the federal Constitution. It need not and ought not become a part of our emerging state constitutional theory.

Attaching positive constitutional theory to normative theory and proceeding thereby to map out the domain of normative theory raises, however, a series of problems about which we ought to be attentive. Those of us engaged in the enterprise of state constitutional theory like to think that we are working on a comparative project; that is, we hope to generalize about state constitutions, rather than remain focused solely on our own state's problems and conditions. State constitutional theory is comparative in two different senses: First, we compare state constitutions with one another in order to yield generalizations about state constitutionalism. Second, we compare state constitutions with the national Constitution, in order both to enrich our theory of federalism and to examine ways in which state and national constitutional processes can learn from one another. ${ }^{30}$

Comparative constitutional theory is extremely difficult, however, since we need to achieve a better understanding of the common elements, as well as differences, in the positive theory of constitutionalism and the positive theory of constitutional law in the fifty state constitutions. Such a comparative project is worthwhile. When we begin to think systematically and more empirically about the law and politics of constitution building and of constitutional change, we can generate some useful hypotheses about state constitutions that are testable and revealing. While the challenges facing states are distinct in important ways, there are similar challenges that face all states in early twenty-first century America. These challenges include welfare policy in the postreform world, criminal justice and penal policy, the role of state and local governments in the delineation and enforcement of rights,

30. For a skeptical view of the extent to which we can learn anything useful from state constitutions in either sense, see James A. Gardner, The Failed Discourse of State Constitutionalism, 90 MrCH. L. REV. 761, 763 (1992). 
and confronting modern urban problems and conditions. Insofar as state constitutions represent the basic, fundamental legal environment in which we as citizens-in our capacity as voters, policy-makers, and members of local polities-make decisions, engaging matters of state constitutional theory means engaging as well this range of pertinent policy issues.

If we are successful in our efforts to generate a useful prescriptive constitutional theory that ties together questions raised in our fifty different state contexts, we will have performed an important public service indeed. This Essay's aim has been to describe the ways in which the theoretical underpinnings of these efforts require mapping out more carefully the domain of normative constitutional theory in light of the distinct nature of state constitutionalism. 